\title{
Home-School Communication Practices in Primary Schools in Kenya
}

\author{
Benard Omenge Nyatuka (Corresponding Author) \\ Department of Educational Foundations, Kisii University, \\ P.O Box 408-40200, Kisii, Kenya. \\ E-mail: bomenge@yahoo.com \\ Eleanor Maud Lemmer \\ Department of Educational Foundations, University of South Africa, \\ P. O. Box 392, Unisa, 0003, South Africa. \\ E-mail: Lemmeem@unisa.ac.za
}

Received: September 26, 2017

Accepted: October 26, 2017 Published: February 20, 2018

doi:10.5296/jet.v5i1.12703

URL: http://dx.doi.org/10.5296/jet.v5i1.12703

\begin{abstract}
Effective two-way communication between the parents and schools is crucial in realizing meaningful learning among children. However, home-school communication was reported to be poor, especially among primary schools in Kakamega County, Kenya. Thus, this study sought to ascertain the effectiveness of family-school communication practices in these schools. A literature review concerning family-school communication and interviews were conducted. Twelve parents, thirteen Parent Teacher Association (PTA) chairpersons and ten District Quality Assurance and Standards Officers (DQASOs), as being information-rich informants, were purposively sampled for the interviews. Semi-structured individual interviews, guided by interview schedules were used. The presentation of the relevant data was done in a narrative format substantiated by verbatim quotations. The findings revealed inadequacies in as far as home-school communication was concerned. It was established that the family-school communication practices in the county were largely ineffective. The findings could be used to improve practice with intent to enhance meaningful learning among the children.
\end{abstract}

Keywords: Communication, home-school partnership, interviews, Kakamega County, Kenya, Practice 


\section{Introduction}

Studies indicate that there are significant benefits of collaboration between families and schools (Epstein \& Sheldon, 2006; E-Lead, 2008; Florez, 2011). For instance, the learners increasingly enjoy what is being taught and learnt at school, better achievements and grades scored in tests, improved behaviour, increased homework completion rates, higher participation in academic activities as well as increased attendance at school with fewer cases involving referrals to special education. Similarly, the educators experience greater job satisfaction, more positive evaluation ratings from the parents and administrators and improved collaborations with their families. On the other hand, the parents experience enhanced self-efficacy, better understanding and more positive experiences with the educators and the schools, among other benefits.

To build strong home-school partnership, effective two-way communication is paramount in respect of the school programmes, and the students' academic and behavioural progress. According to Epstein and Sanders (2006), it is increasingly becoming clear that the educators need to know more about how to communicate effectively, to share ideas, to solve problems and to work together as members of teams with other educators, the parents and community members. In particular, the schools should be accountable for reaching the families and for providing them with the information about the school's progress and student performance. Accordingly, the means of communication should be appropriate for the parents and their cultural specifications while the process needs to be bidirectional (Green, Walker, Hoover-Dempsey \& Sandler, 2007; Obeidat \& Al-Hassan, 2009; Petronic, n.d.).

According to E-Lead (2008), parental involvement should include the participation of the parents in regular, two-way and meaningful communication involving the learners' academic learning, behaviour as well as other school activities. Similar views are echoed by Epstein and Sheldon (2006) as well as Florez (2011) who hold that the importance of parental participation in the educational process implies developing new social and political meanings that will contribute to the poor, rural schools increasingly becoming places for dialogue and an opportunity for a meeting of the minds and experiences among children and adults.

A study involving elementary school principals from middle-class neighbourhoods in urban Alberta, Canada, revealed that building firm relationships and regular communication enhanced learning among young children (Rygus, 2012). Indeed, the principals appreciated the fact that despite relationship building being demanding with respect to time and related resources, it was a worthwhile undertaking. They also agreed that it is the school's responsibility to strengthen such collaboration with the parents. Another study revealed that learners who receive their parents' support for their education and enjoy good communication are more likely to continue their studies beyond the secondary school cycle of education (Erlendsdottir, 2010).

To develop positive family-school collaboration, the schools should create an environment and culture that is invitational for all families (National Association of School Psychologists-NASP, 2005). This involves consistently sending messages home, including to those with limited literacy skills or educational resources. The schools should also encourage 
collaboration by eliciting and understanding the perspectives and expectations of the parents. The fact that individual families from diverse backgrounds will support their children in different ways should be recognized. Accordingly, the schools should also provide space for parental decision-making and governance, provide time for the teachers to meet with the families in the community and create a family support system in the school. And, since families are diverse and have different perspectives, expectations and communication styles, the schools need to provide training for the staff and the families that encourages understanding and a celebration of diverse family norms, cultures, ethnicities, linguistic backgrounds and socio-economic status (NASP, 2005).

Particularly, diversity should be viewed as a strength that provides multiple perspectives and information about a child. Indeed, collaboration is based on the assumption that families, children and educators are just doing the best they can, and not judge them as either being right or wrong (NASP, 2005). Obeidat and Al-Hassan (2009) assert that since family-school collaboration is a process guiding the development of goals and plans, it should be characterized by open communication, mutually agreed-upon goals and joint decision-making.

To have a participatory process of analyzing the complex issues affecting the quality of education, especially in rural schools, the community needs to be successfully engaged. To achieve this however, it is important to see to it that its cultural practices are honoured (Florez, 2011). Accordingly, priority should be given to the children's interactions with their sources of knowledge, including the community and the municipality, classmates, the school, the teachers and families. Particularly, two-way communication with the community is critical. Among others, the community should be kept informed of school actitvities by a hotline, by parent-teacher association news or by notices of school programmes (Madison, 2000).

To improve home-school communication, the community can also work closely with the school through volunteers. For example, this can realized by giving non-school personnel an opportunity in the classroom to address the children about daily problems and issues in the society (Florez, 2011; Epstein et al., 2002; Madison, 2000). However, those who volunteer should undergo an orientation session so that they are clear about their role in the classroom (Madison, 2000). Community volunteers can learn the school's routine, shop for and package materials that may be used in class, or work with individual learners on such areas as science, mathematics, reading skills, word-recognition or the editing of homework projects. Another way to boost interaction between the school and the community is to have a project on the flora or fauna in the area, as this will give the children many opportunities to improve their oral and written language skills (Florez, 2011; ROK, 2010). Enriched learning activities help the learners to do better at school.

The preceding literature reiterates the need for both families and schools to be dependable partners so as to ensure provision of quality education to children. In particular, the crucial role that effective communication plays towards this end has been emphasized. But there are a number of obstacles that work against this endeavor, some of which are highlighted in the following section. 


\subsection{Obstacles to effective home-school communication}

There are many barriers that hinder effective communication between families and schools. Glasgow and Whitney (2009) observe that parents and teachers have a misconception about each other's vision for parental involvement. According to Erlendsdottir (2010), parents do not always respond to communication from the school, hence the teachers may feel that the parents are not interested in becoming involved. Accordingly, the parents often believe that the teachers do not actually desire their involvement. Some parents and teachers often believe that the learners may not appreciate or support their parents' involvement. In particular, some teachers feel that the parents of teenagers should never be too involved. They therefore, actively discourage the parents from participating in the relevant activities (Erlendsdottir, 2010; Richardson, 2009).

Nichols and Read (2002) and Lemmer (2013) note that a significant obstacle to meaningful communication is the traditional parent-teacher conference that only lasts 5-15 minutes. A meeting that is so short does not allow meaningful communication about the child's academic and social progress. Cultural differences also cause communication problems, especially if the teachers rely on their own cultural interpretations while interacting with heterogenous groups of parents. Similarly, Erlendsdottir (2010) and Richardson (2009) note that the parents' own negative school experiences may affect the building of a positive relationship with their children's teachers. Christenson and Sheridan (2001) mention financial and time constraints as other obstacles to effective communication between the teachers and the parents. In addition, the educational jargon that schools often use with the parents hinders effective communication between families and schools (Erlendsdottir, 2010).

As per NASP (2005), working with families and communities will always be one of the more challenging tasks for educators and may frustrate many otherwise willing teachers. Accordingly, families and educators often differ in their expectations, goals and communication patterns, sometimes leading to annoyance and misunderstanding among learners, families and educators. Open communication is therefore essential in order for the educators and families to understand and respect each other's perspectives (Hoover-Dempsey, Walker, Sandler, Whetsel, Green, Wilkins \& Closson, 2005).

Epstein (2009) observes that the schools need to overcome challenges to family-school partnerships by providing the opportunities for school-home and home-school communication in a language and at a reading level all families can understand, ensuring adequate representation of the entire community of parents on school advisory councils or the school governing bodies, and disseminating information provided during workshops to the families who could not attend. Accordingly, the schools that make these kinds of efforts to reach all families will reap the rewards of appreciation from all the parents, thereby improving the achievement of all the learners. Furthermore, to address obstacles to parental involvement, teacher training, both pre- and in-service, should cover the topic of parental involvement (The Net Industries, 2013). On the whole, teacher training programmes provide both time and curriculum space to parental invovelment (Epstein, 2013). 
But effective family-school partnership should extend further than merely addressing these obstacles and should include discussing and determining the rights, roles, responsibilities and resources of the families, school staff and the learners (NASP, 2005). Florez (2011) observes that the traditional tension between the teachers and the learners and among the teachers and the family should be replaced by conversation. In addition, the teachers should consider the social and cultural contexts of the individual families and their offspring. As a professional obligation, the teachers should develop constructive attitudes, philosophies, communication and practical skills to build productive relationships with the families (Getswicki, 2010). Among others, a sincere understanding of parenting is essential to determine positive home-school partnerships (Epstein et al., 2002).

\subsubsection{Statement of the problem}

Despite the critical role played by effective communication in building sound family-school partnerships in the promotion of meaningful and engaged learning among the learners, there seems to be little effort being made to enhance them in primary schools in Kenya's Kakamega County. This was indicated during a workshop involving stakeholders in education where the participants felt that communication involving families and schools was poor (Ministry of Education-MOE, 2010). This has been considered to be a major impediment to the provision of quality education and in the implementation of government policies. Against this background, this study sought to explore the effectiveness of home-school communication practices among primary schools in Kakamega County.

The key research question was formulated thus:

How effective are home-school communication practices in primary schools in Kakamega County, Kenya?

The main research question was sub-divided into the following questions:

i) What are the practices regarding home-school communication in primary schools in Kakamega County, in a selected sample of primary schools as revealed through interviews with parents, Parent Teacher Assocation (PTA) chairpersons and District Quality Assurance and Standards Officers (DQASOs)?

ii) What are the barriers to effective home-school communication in primary schools in Kakamega County?

ii) Based on the findings of the literature study and the empirical inquiry, what recommendations can be made for the improvement of practice of the home-school communication in primary schools in Kenya with special reference to Kakamega County?

\section{Method}

The problem was investigated by means of a literature study and an empirical investigation using interviews involving parents, PTA chairpersons and DQASOs. It is worth noting that the DQASOs were included in this study due to their good level of knowledge on matters to do with basic education and home-school partnerships. Twelve parents, thirteen PTA 
chairpersons and ten DQASOs were purposively sampled to be interviewed in this study. In purposive sampling, the researcher's judgment is used to select those respondents who best meet the purposes of the study (Mugenda \& Mugenda, 2003). While the deviant case sampling strategy (Mertens, 2005) was used to select those parents who possessed limited knowledge regarding children's learning, the intensity sampling strategy applied to the PTA chairpersons.

The parent participants and the PTA chairpersons were selected from 34 primary schools while the DQASOs represented ten of the twelve districts in the county. Individual semi-structured interviews using researcher-designed interview guides for the parents and the PTA chairpersons as well as DQASOs were conducted. The data were analyzed qualitatively. In particular, the recorded interviews were transcribed, and the data generated analyzed by means of content analysis, a technique that can be used to examine information or content, in written or symbolic material (Neuman, 2000). And, being an ethical requirement, informed consent was sought from the participants.

In analysing the data from the interviews a coding methodology was used, namely transcribing the interviews, conducting a textual analysis to identify numerous codes, clustering these into code 'families', identifying several emergent themes from the code families, linking the identified themes to the literature study, presenting the findings and finally, offering recommendations. The presentation of the qualitative data was in a narrative form, backed by verbatim quotations.

\section{Findings and discussions}

According to Green et al. (2007), the teachers' invitations to the parents to become involved in education are particularly influential to the students' educational success. This assertion is echoed by Hoover-Dempsey et al. (2005). The findings in this study indicated that the PTA chairpersons had met their children's teachers.

"Since I come to school often, I interact with the teachers a great deal," said one PTA chairperson.

Another PTA chairperson concurred, "The nature of my work dictates that I make frequent appearances at school. This creates opportunities to meet the teachers."

A PTA chairperson added: "Regular visits to school enable me to monitor children's progress in both class and behavior. There are things a parent may fail to notice early enough in a child as opposed to the teachers. Therefore, frequent visits help in such circumstances."

Regular visits to the school by the PTA chairpersons had led to improved achievements in the children's education.

"Due to my regular visits to school in the last two years, pupils' mean score in the end of term tests has steadily improved," revealed a PTA chairperson.

"Teachers need to be motivated or encouraged to do their best. Thus, I spare time to do the same," observed another PTA chairperson. 
However, the regularity with which PTA chairpersons met with the teachers could be attributed to the leadership roles they play in their respective schools which then requires frequent visits to the school.

It is important to note that comprehensive parental involvement should include all the parents in regular, two-way and meaningful communication regarding the pupils' academic progress, conduct and other school activities (E-Lead, 2008). In this study, the parent participants who were not in leadership positions did not have the same frequency of contact that the PTA members had with the school. A common barrier was the workload of the parents. A father, a casual labourer and peasant farmer, explained that he had not yet met his children's teachers.

He said, "Not that I don't wish to meet teachers, but I virtually fail to get time due to the tight schedule."

This finding reinforces the assertion by Erlendsdottir (2010) that the parents' work schedules may conflict with school events, thereby making the parents unable to attend them.

According to another parent, "Teachers hardly have time for parents due to their tight schedule. So I rarely plan to meet them."

Another barrier to communication was language, as a parent explained, "I find it hard to go to meet teachers, especially those of them who don't understand my local language which is the only one that I'm able to effectively use."

Thus for some parents, the language spoken by the teachers determines whether they are involved or not, particularly with respect to paying visits to the school.

Transport and distance from the school was also a barrier according to another parent, "Walking for about an hour to get to school is really taxing. Sometimes I can't just make it."

Learners were primarily instructed by the schools to inform their parents verbally to meet the teachers or to deliver notes on the same. Other ways used to achieve such communication included face-to-face encounters. SMSs and phone calls were hardly used to communicate, especially where many parents were involved, due to the costs incurred. Illiterate parents were not able to read SMS messages.

A PTA chairperson confirmed: "Some parents can't be reached whenever SMSs and phone calls are used. This is partly due to the failure to charge their cell phones for lack of a source of power, particularly electricity."

One PTA chairperson and one parent reported that the teachers had made a formal visit to their homes to discuss serious problems, including absenteeism and domestic labour. Accordingly, where one child was a chronic absentee from school due to illness, the other's academic achievement had deteriorated due to excessive involvement in domestic chores. In both cases the teachers provided the relevant pieces of advice which reportedly bore fruit. The concerned PTA chairperson invited the teacher to his home; a village elder accompanied the teacher in the case of the home visit dealing with domestic labour. No home visits were made to commend children or to express appreciation. Obeidat and Al-Hassan (2009) advise 
that the teachers need to contact the homes to notify the parents of a job done well, or in respect of their child's progress, not only when they are lacking in their performance, or their behavior is causing problems.

Furthermore, all except one PTA chairperson and five parents had requested a meeting with the headteachers and parents to deliberate on a variety of issues affecting the children's education in the previous four months. Only four participants observed that the teachers made phone calls to communicate good news about the children. Otherwise, good news was communicated during parent-teacher conferences, and by means of report cards prepared at the end of every school term (i.e., at three month intervals). All the participants except one reported to be comfortable during meetings with the teachers.

"Meetings between teachers and parents are quite informative. I do enjoy the proceedings," reported a parent.

However, the parent who was the exception mentioned, "Every time we have a meeting, the teachers want things to go their way. They've little regard for our views."

Both general and individual meetings between the parents and the teachers took place at school, the church or in the community. The low turnout of the parents at the school meetings remained a key challenge as well.

A PTA chairperson noted thus, "Out of a population of 400, only between 150 to 180 parents could attend meetings convened by my school."

The findings also indicated that occasionally the pupils, especially in day schools, were sent to call their parents to attend the school functions. This was particularly after the parents had failed to form a quorum to conduct the business of the day. The parent participants were not happy with this practice, which involved the child missing school. The participants concurred that the learners should not leave school in order to be sent home to bring their parents to school meetings.

According to one parent, "Not only do pupils waste time meant for learning, but are prone to security risks, leave alone engagement in vices once pupils are sent home in this manner".

They were in agreement therefore, that this practice should be terminated in so far as home-school communication was concerned.

The DQASOs revealed that they sometimes addressed the parents of the children in their respective districts during education days, with the release of the examination results and of the findings of the assessment of quality and standards at the schools. Other avenues through which DQASOs met the parents were reported as at school, sports events, clubs, the church and other social functions. According to the officers, letters, learners as messengers, SMSs and radio broadcasts were common forms of communication involving both the schools and the parents. The use of the radio was particularly common when bringing to the attention of the public functions such as raising funds for the school and visits by important guests, including alumni. While there was regular communication between DQASOs and headteachers, this practice seldom applied to parents. 
"As an office, we more often communicate directly to schools, especially the headteachers in comparison with individual parents, guardians and others, " commented a DQASO.

In the company of relevant officers like the police and social workers, the DQASOs would sometimes visit the learners' homes in cases involving sexual abuse between the teachers and the pupils, child labour, and when assessing the family's socio-economic status, especially that of orphans and the vulnerable, that required different forms of assistance. The DQASOs communicated good news about the schools to both the parents and the community, using means such as summarized reports or circulars, at Annual General Meetings (AGMs), and during education days and sports days. Like the PTA chairpersons and parents, the DQASOs condemned the practice of sending pupils home during class hours to ask their parents to attend school meetings. They strongly advised that other appropriate options be devised.

One DQASO argued that officers at the district education office mostly made use of a top-down approach with respect to communication with the schools. This is appropriate in an administrative context. However, it is less effective when the schools used this approach with the parents.

A DQASO observed, "Most school managers, including Boards of Managements (BOMs) and PTAs more often than not stage manage AGMs and parent-teacher conferences, with minimal participation from the parents, in a bid to run away from transparency and accountability, especially where there is fraud and related issues."

As revealed in school assessment reports compiled by the DQASOs in their respective areas of jurisdiction, a number of managers of schools do engage, particularly in financial mismanagement as well as fraud. In such instances, the law normally takes its course.

The findings in this study reveal that in comparison with PTA chairpersons, the parents in general have a much lower level of interaction with the schools. This could be due to the low level of formal education among a number of the latter and engagement in socio-economic activities in an effort to earn a living.

\section{Conclusion and recommendations}

Both the reviewed literature as well as the empirical investigation underscore the significance of building strong family-school partnerships. This is quite important if meaningful learning among the learners is to be achieved. Apparently, effective two-way communication between families and schools is crucial in a bid to develop the desired collaboration. But as revealed in this study, such challenges as tight work schedules, inadequate teacher preparation, long distances to school, language barrier and ignorance render communication ineffective to yield the anticipated goals. The situation is further complicated by the level of intolerance among the key stakeholders. Particularly, this study established that some school managers hardly entertain parents' views during AGMs and conferences, thereby stifling the constitutional provisions with regard to freedom of expression, public participation and democracy.

The practice of sending the learners home during school hours for whatever reason was roundly castigated by the participants in this study. There were numerous risks associated 
with this practice, including those to do with insecurity, let alone wasting essential learning time. And, although they are generally known to be popular means of home-school communication, newsletters, e-mails and message books sent home on a daily basis were found to be used very seldom in the schools in the county. Generally, poor curriculum implementation, negative attitudes, inadequate pre-service as well as in-service teacher preparation and inept leadership abilities contributed to weak family-school partnerships, including communication practices. Particularly, it was revealed that due to heavy teaching load, most of the teachers did not have the time to communicate to the parents and the community at large. It is worth noting however, that even if they were invited to school, many parents did not honour this due to involvement in farm and domestic chores, among other reasons.

To rectify this scenario therefore, there is need to hire more teachers, enhance capacity-building, including proper sensitization among the key stakeholders in the education sector in the county. This study revealed that lack of the prerequisite infrastructure, including electricity, information communication technology skills among the stakeholders, and poverty were partially to blame for the inappropriate communication practices among schools in the county. Thus, combined efforts involving the national and county governments, the schools, the individuals and the relevant institutions should be initiated to surmount these challenges. Since this study found that face-to-face meetings involving the families and the community members were more effective compared to other ways of communication between the home and the school, they should be encouraged whenever this is possible.

\section{References}

Christenson, S. L., \& Sheridan, S. M. (2001). Schools and families: Creating essential connections for learning. New York: Guilford Press.

E-Lead. (2008). Connecting schools, families and communities. Washington D.C.: Leadership for success partnership. Retrieved January 7, 2013, from http://www.e-lead.org/ principles/connection.asp

Epstein, J. L. (2009). School, family and community partnerships: Your handbook for action. (3rd ed.). Baltimore: Corwin Press.

Epstein, J. L. (2013). Family, school, community engagement, and partnerships: An imperative for $\mathrm{K}-12$, and Colleges of Education in the development of twenty-first-century educators. Teaching Education, 24(2), 115-118.

Epstein, J. L., \& Sanders, M. G. (2006). Prospects for change: Preparing educators for school, family and community partnerships. Peabody Journal of Education, 81(2), 81-120.

Epstein, J. L., \& Sheldon, S. B. (2006). Moving Forward: Ideas for Research on School, Family and Community Partnerships. In F. C. Conrad \& R. C. Serlin (eds.). Handbook for research education: Engaging ideas and enriching inquiry. Thousand Oaks, California: Sage Publications.

Epstein, J. L., Sanders, M. G., Sheldon, S. B., Simon, B. S., Salinas, K. C., Jansom, N. R., \& 
Williams, K. S. (2009). School, family and community partnerships: Your handbook for action. (3rd ed.). Thousand Oaks, CA: Corwin.

Epstein, J. L., Sanders, M. G., Simon, P. S., Salinas, K. C., Jansom, N. R., \& Van Voorhis, F. L. (2002). School, family and community partnership: Your handbook for action. (2nd ed.). Corwin: Thousand Oaks, CA.

Erlendsdottir, G. (2010). Effects of parental involvement in education. A case study in Namibia. Unpublished M.Ed. dissertation. Iceland, University of Iceland.

Florez, A. (2011). Active schools: Our convictions for improving the quality of education. Washington D.C.: FHI 360.

Getswicki, C. (2010). Home, school and community relations: A guide book to working with families. $\left(7^{\text {th }}\right.$ ed.). Belmont, CA: Wadsworth Cengage learning. Retrieved June 4, 2012, from http://www.edrev.infor/brief/june10.pdf

Glasgow, N. A., \& Whitney, P. J. (2009). What successful schools do to involve families: 55 Partnership strategies. New York: Corwin Press.

Green, C. L. Walker, J. M. T., Hoover-Dempsey, K. V., \& Sandler, M. H. (2007). Parents' motivations for involvement in children's education: An empirical test of a theoretical model of parental involvement. Journal of Educational Psychology, 99(3), 532-544.

Hoover-Dempsey, K. V., Walker, J.M.T., Sandler, H. M., Whetsel, D., Green, C. L., Wilkins, A. S., \& Closson, K. E. (2005). Why do parents become involved? Research findings and implications. Elementary School Journal, 106, 105-130.

Lemmer, E. M. (2013). The parent-teacher relationship as partnership: A conceptual analysis. Journal for Christian Scholarship, 49(1 \& 2), 25-54.

Madison, L. (2000). Home-school-community partnerships. New Jersey: Houghton Mifflin Company. Retrieved February 25, 2012, from http://www.eduplace.com/science/ profdev/articles/madison.html

Mertens, M. D. (2005). Research and evaluation in education and psychology: Integrating diversity with quantitative, qualitative and mixed methods. (2nd ed.). Thousand Oaks, CA: Sage Publications.

Ministry of Education (MOE). (2010). Western Province sensitization workshop on re-engineering education for quality performance. Kakamega: Western Province Education Office.

Mugenda, O. M., \& Mugenda, A. G. (2003). Research methods: Quantitative and qualitative approaches. Nairobi: Acts Press.

National Association of School Psychologists (NASP). (2005). Position statement on home-school collaboration: Establishing partnership to enhance educational outcomes. Retrieved July 1, 2013 http://www.nasponline.org/about_nasp/pospaper_hsc.aspx 
Neuman, W. L. (2000). Social research methods: Qualitative and quantitative approaches (4th ed.). Boston: Allyn \& Bacon.

Nichols, S., \& Read, P. (2002). 'We never knew it was that bad': Parent-school communication about children's learning difficulties. Australian Journal of Language and Literacy, 25(3), 49-63.

Obeidat, O. M., \& Al-Hassan, S. M. (2009). School-parent-community partnerships: The experience of teachers who received the Queen Rania Award for Excellence in Education in the Hashemite Kingdom of Jordan. The School Community Journal, 19(1), 119-136.

Petronic, M. (n.d.). Family-school partnerships models: Epstein's Theory of Parental Involvement. Retrieved July 13, 2013, from http://www.see-educoop.net/aeiq/ documents

Republic of Kenya (ROK). (2010). Child Friendly School Manual. Nairobi: Ministry of Education.

Richardson, S. A. (2009). Principals' perceptions of parental involvement in the "Big 8" urban districts of Ohio. Research in the Schools, 16(1), 1-12.

Rygus, E. (2012). Parental involvement in our schools: Practical ways for principals to encourage parental involvement. Alberta: The Alberta Teachers' Association. Retrieved August 21, 2013, from http://www.teachers.ab.ca/Publications/ATA

The Net Industries (TNI). (2013). Parental involvement in education: Research on parental involvement, effects on parental involvement, obstacles to parental involvement, controversies, current issues. Retrieved March 17, 2014, from http://education.stateuniversity.com/pages/2309/Parental-Involvement-in-Education.htm 1

\section{Copyright Disclaimer}

Copyright reserved by the author(s).

This article is an open-access article distributed under the terms and conditions of the Creative Commons Attribution license (http://creativecommons.org/licenses/by/3.0/). 